\title{
Komparasi Kompetensi Santri Asrama Dan Non Asrama Dalam Berkomunikasi Di Lingkungan Pesantren Ulil Albaab
}

\author{
Baiq Yulia Kurnia Wahidah \\ Institut Pendidikan Nusantara Global \\ JL. Raya Praya Mantang KM 07 Lombok Tengah \\ Email: yuliakurnia_wahidah@yahoo.com
}

\begin{abstract}
Abstrak.Tujuan dari penelitian ini adalah untuk mengetahui tingkat kompetensi komunikatif yang dimiliki oleh santri asrama dan nonasrama di Pondok Pesantren Ulil Albaab. Jenis penelitian ini adalah penelitian Kuasal Komparatif (Exs Post Facto). Sampel dari penelitian ini adalah santri asrama dan nonasrama. Jumlah subjek 30 santri, di mana kelas asrama berjumlah 15 dan kelas nonasrama berjumlah 15 santri. Untuk mengukur tingkat kemampuan kompetensi komunikatif yang dimiliki oleh para santri digunakan instrumen, instrumen yang digunakan adalah angket yang berisi kriteria-kriteria penilaian dalam kompetensi komunikatif berpidato.Berdasarkan hasil analisis data diperoleh santri asrama memiliki kompetensi yang lebih baik dari santri asrama, dengan perhitungan hasil nilai santri asrama memiliki nilai tertinggi 92 dengan rata-rata 84.2 sedangkan santri nonasrama memiliki nilai tertinggi 76 dengan nilai rata-rata 58,7. Sehingga hipotesis Ha diterima dengan adanya perbedaan kompetensi komunikatif antara santri asrama dan nonasrama di Pondok Pesantren Ulil Albaab, dan menolak hipotesis 0 atau Ho.
\end{abstract}

\section{Kata kunci: komparasi kompetensi komunikatif, santri asrama dan nonasrama.}

\section{LATAR BELAKANG}

Manusia adalah makhluk individu dan juga makhluk sosial yang tidak terlepas dari proses berinteraksi dengan yang lainnya. Melalui proses intera ksi manusia akan dapat saling mengenali antara satu dengan yang lainnya. Salah satu pendekatan yang dilakukan manusia dalam berinteraksi adalah dengan cara berkomunikasi. Berkomunikasi merupakan suatu kegiatan yang dilakukan oleh manusia untuk mendapatkan informasi-informasi yang mereka butuhkan. Berkomunikasi tidak terlepas dari proses berbahasa dan penggunaan bahasa dalam kehidupan sehari-hari. Melalui proses berbahasa manusia dapat menuangkan segala ide, pikiran, maupun gagasan yang dimilikinya. Penggunaan bahasa akan didukung bila adanya suatu masyarakat yang akan menggunakan bahasa tersebut. Bahasa itu akan berkembang apabila masyarakat pemakainya dapat mengembangkan bahasa itu dengan baik. Masyarakat bahasa adalah sekumpulan manusia yang menggunakan sistem isyarat bahasa yang sama Blomfield (dalam Ghazali,2010: 49) Corder (dalam Aslinda, 2007: 8) mengatakan, bahwa masyarakat bahasa adalah sekelompok orang yang satu sama lain bisa saling mengerti sewaktu mereka berbicara.

Pembelajaran dalam bahasa tidak terlepas dari proses belajar mengajar. Pembelajaran dalam bahasa dilaksanakan dalam lingkungan formal maupun informal. Di lingkungan formal proses pembelajaran bahasa itu berlangsung di sekolah, baik dari jengjang Sekolah Dasar sampai dengan Perguruan Tinggi. Sedangkan proses pembelajaran yang berada di lingkungan informal berlangsung di luar sekolah. Proses pembelajaran para santri yang ada di lingkungan pondok pesantren juga memiliki kaitan dengan prose pembelajaran yang secara umum. Proses pembelajaran bahasa yang dilaksanakan di lingkungan pondok pesantren diberikan dalam dua lingkungan yaitu lingkungan formal dan lingkungan nonformal. Pembelajaran yang diberikan di lingkungan formal akan mengarah pada semua santri yang ada di lingkungan pondok pesantren baik yang tinggal di asrama maupun yang tidak tinggal di asrama. Secara formal mereka akan mendapatkan pembelajaran yang sesuai dengan kurikulum yang berlaku. Sedangkan proses pembelajaran yang ada di lingkungan nonformal atau pembelajaran yang dilakukan di luar 
sekolah atau dalam asrama adalah khusus bagi santri yang tinggal di dalam asrama tersebut. Para santri yang tinggal di dalam asrama akan mendapatkan tambahan pembelajaran mengenai bahasa dan mereka akan lebih ditekankan pada praktik-praktik berdasarkan teori yang telah diberikan.

Kompetensi berbahasa akan lebih baik jika ditunjang dengan proses pembelajaran bahasa yang berupa teori-teori serta ditambah dengan latihan-latihan. Latihan-latihan tersebut akan memperkuat kompetensi yang ada dalam diri seorang santri tersebut. Kompetensi yang dimiliki oleh para santri ternyata memiliki perbedaan.Bagi santri yang tinggal di asrama menunjukkan kemampuan yang lebih dalam kompetensi komunikasi, dibandingkan dengan santri yang tidak tinggal di asrama kompetensi berbahasa mereka masih kurang.Pendekatan komunikatif dalam pembelajaran bahasa didasarkan atas apa yang dinamakan kompetensi komunikatif (Communicative competence). Kompetensi komunikatif menurut Kridalaksana (dalam Ghazali,2010: 49 ) adalah kemampuan bahasawan untuk mempergunakan bahasa yang secara sosial dapat diterima dan memadai. Dalam pembelajaran komunikasi bagi siswa yang ada di asrama harus menggunakan bahasa secara produktif dan dapat diterima, dalam konteks-konteks yang tertentu.

Perbedaan kompetensi komunikasi yang dimiliki oleh santri yang berada di lingkungan asrama lebih tinggi bila dibandingkan dengan santri yang tidak tinggal di asrama. Dilihat dari hasil observasi yang telah dilakukan santri asrama memiliki kemampuan komunikasi yang lebih baik, para santri dapat menggunakan penggunaan bahasa yang lebih produktif,lebih baik dan sopan dibandingkan dengan santri yang tidak tinggal di asrama. Santri yang tidak tinggal di asrama memiliki kemampuan berkomunikasi yang masih kurang dibandingkan dengan santri yang tinggal di asrama.Perbandingan dari kemampuan berkomunikasi yang dimiliki oleh santri disebabkan karena, santri asrama diberikan pembelajaran berupa teori-teori yang diperkuat dengan laihan-latihan setiap harinya.Sehingga para santri terbiasa menggunakan bahasa yang produktif. Namun, bagi santri yang tidak tinggal di asrama mereka hanya mendapatkan pembelajaran yang ada di sekolah dengan tidak diperkuat melalui berlatih.Selain dari itu, para santri juga harus menggunakan dua bahasa asinyaitu bahasa Arab dan bahasa Inggris sebagai bahasa keseharian mereka. Para santri hanya diperbolehkan menggunakan bahasa Indonesia hanya dalam kurun waktu enam bulan dengan tidak menggunakan bahasa asli mereka. Dalam kurun waktu enam bulan tersebut, mereka akan mendapatkan pengajaran mengenai pembelajaran bahasa asing melalui tutor sebaya.

Maka, untuk itulah perlu adanya suatu penilaian untuk dapat mengetahui sejauh mana letak perbedaan santri asrama dan santri yang tidak tinggal di asrama dalam kemampuan berkomunikasi.Sehingga kita dapat memberikan kesimpulan bahwa kompetensi komunikatif itu memiliki perbandingan pada suatu konteks tertentu. Penggunaan bahasa juga akan lebih sopan dan terarah apabila pembelajaran bahasa dilaksanakan dengan berlatih.

\section{KAJIAN PUSTAKA}

\section{A. Landasan Teori \\ 1. kikat Kompetensi}

Kompetensi atau "Competence" secara harfiah diartikan sebagai kemampuan atau kapabilitas. Kompetensi didefinisikan sebagai gambaran tentang apa yang harus diketahui atau dilakukan seseorang agar melakukan sesuatu dengan baik, atau kompetensi didefinisikan juga sebagai sesuatu (rencana) yang menggambarkan bagaimana seseorang diharapkan mampu berprilaku agar seseorang dapat melaksanakan pekerjaannya dengan baik. Sesuatu yang diharapkan untuk dikuasai dan ditunjuknyatakan (perpormance) seseorng (pesertadidik), aspekaspeknya dapat berupa pengetahuan keterampilan, sikap sikap maupun nilai-nilai dasar, (Supriadi, dkk 2012: 98).

Pengertian "kompetensi" bahasa telah digunakan untuk mengkarakterisasikan pengetahuan penutur yang mendasari sistem bahasa,termasuk kaidah-kaidahnya untuk menghasilkan kalimat-kalimat gramatikal Chomsky (dalam Tarigan, 2009: 21). Kompetensi adalah penguasaan atas sistem dari aturan-aturan bahasa yang benar-benar dihayati, yang memungkinkan kita untuk mengenal struktur batin dan struktur lahir, untuk dapat 
membedakan antara kalimat yang benar dan kalimat yang salah, dan untuk mengerti kalimatkalimat yang belum pernah kita dengar atau kita katakan sebelumnya. Makna kompetensi adalah pengetahuan pembicara-pendengar asli secara tidak sadar, diam-diam/tidak diucapkan, instrinsik/hakiki, implisit, intuitif, dan tidak terbatas oleh bahasanya.Dalam kebahasaan struktur dan kosakata perlu mendapat perhatian secara khusus, meskipun secara umum dalam pembelajaran dan tes bahasa lebih ditekankan pada fungsi komunikatif bahasa (Nurgiyantoro,2010: 281).

Melalui tes kompetensi kebahasaan dapat diketahui kompetensi kebahasaan bagi peserta didik ataupun bagi santri yang berada pada lingkungan pondok pesantren. Melalui pembelajaran yang diberikan kepada para peserta didik atau santri yang berada dalam lingkungan pondok pesantren akan memberikan dampak yang lebih besar terhadap kompetensi kebahasaan. Dibandingkan dengan pembelajaran yang hanya diberikan pada lingkungan formal atau sekolah tidak akan memberikan hasil yang maksimal untuk kompetensi kebahasaan. Karena bagi peserta didik yang tinggal di asrama akan diberikan pembelajaran yang lebih dan pembelajaran tambahan khususnya dalam kompetensi kebahasaan.

Dikatakan bahwa bahasa seseorang mencerminkan pikirannya.Semakin terampil seseorang dalam berbahasa maka semakin jelas dan cerah jalan pikirannya. Keterampilan tersebut akan dapat diperoleh dari praktik dan banyak latihan. Melatih keterampilan berbahasa juga akan melatih keterampilan berpikir. (Tarigan,2009: 27).

\section{Pengertian Komunikatif}

Komunikasi adalah pertukaran ide-ide, gagasan-gagasan, informasi dan sebagainya antara dua orang atau lebih. Dalam suatu tindak komunikasi biasanya terdapat paling sedikit setiap orang pembicara, dan seorang atau lebih sebagai tujuan penyampaian pesan, yaitu penerima "receiver" Richard $\mathrm{dkk}$ (dalam Tarigan, 2009: 14). Berkomunikasi adalah suatu tindakan sosial yang dilakukan oleh makhluk sosial, suatu tindakan untuk saling bertukar pikiran, pengalaman, mengemukakan pendapat, gagasan, ide, maupun untuk menerima pendapat dari orang lain, untuk mengekspresikan dan mengutarakan perasaan. Oleh karena itu, di dalam suatu tindakan sosial harus ada elemenelemen umum, yang sudah disetujui dan dipahami oleh sejumlah orang yang merupakan suatu masyarakat.

Masyarakat bahasa adalah sekumpulan manusia yang menggunakan sistem isyarat bahasa yang sama Blomfield (dalam Aslinda, dkk 2007: 8). Pengertian masyarakat bahasa menurut Blomfield oleh para ahli sosiolinguistik dianggap terlalu sempit karena setiap orang menguasai dan menggunakan lebih dari satu bahasa. Corder (dalam Aslinda, dkk, 2007: 8) mengatakan, bahwa masyarakat bahasa adalah sekelo mpok orang yang satu sama lain bisa saling mengerti sewaktu mereka berbicara. Komunikasi dapat dipandang sebagai suatu kombinasi perbuatan-perbuatan atau tindakantindakan serangkaian unsur-unsur yang mengandung maksud dan tujuan.

Dari definisi di atas, komunikasi dapat diartikan sebagai suatu bentuk proses berkomunikasi dalam berinteraksi sehari-sehari. Melalui berkomunikasi manusia dapat saling mengerti antara satu dengan yang lainnya.Berkomunikasi merupakan suatu alat untuk menyampaikan ide, gagasan, pikiran, maupun yang lainnya yang dimiliki oleh manusia itu sendiri. Proses berkomunikasi juga tidak bisa terlepas dari masyarakat pemakainya, karena masyarakatlah yang akan melakukan komunikasi dengan satu alat yaitu bahasa. Bahasa merupakan satu media komunikasi yang memegang peranan penting dalam kehidupan sehari-hari. Begitu juga dengan kondisi yang ada bagi santri asrama dan nonasrama, mereka akan berkomunikasi dengan menggunakan bahasa yang sudah ditetapkan di asrama.

\section{Pengertian Kompetensi Komunikatif}

Kompetensi komunikatif adalah kemampuan untuk menerapkan kaidah-kaidah gramatikal suatu bahasa untuk membentuk kalimat-kalimat yang benar secara gramatikal dan untuk mengetahui di mana menggunakan kalimat-kalimat tersebut dan kepada siapa (Tarigan ,2009: 31). Istilah kompetensi komunikatif telah banyak kita dengar dan banyak dipergunakan oleh sejumlah orang sejak 
tahun 1970-an untuk menggambarkan kemampuan yang lebih luas dari pada kemampuan yang berkaitan dengan pengetahuan gramatikal bahasa.Pengertian yang lebih luas mengenai kompetensi komunikatif melibatkan aspek-aspek semacam suatu kaidahkaidah sosial dan fungsional penggunaan bahasa bersama dengan keterampilan-keterampilan yang diperlukan untuk menegosiasikan makna secara interpersonal dalam situasi-situasi sosiolinguistik tertentu.Kompetensi komunikatif mengacu pada kemampuan untuk berkomunikasi secara efektif, (Devito, 2011: 26). Kompetensi ini akan mencakup hal-hal seperti pengetahuan tentang peran lingkungan (konteks) dalam mempengaruhi kandungan (content) dan bentuk pesan komunikasi. Kompetensi komunikatif tidak terlepas dari kompetensi yang lain seperti kompetensi linguistik, kompetensi pragmatik, kompetensi sosiolinguistik, kompetensi gramatikal, kompetensi wacana, kompetensi strategik (Tarigan, 2009: 33). Kaitannya dengan kemampuan komunikasi dan berbahasa yang dimiliki oleh peserta didik atau santri yang berada dalam lingkungan pondok pesantren dapat diketahui dari pemaparan di atas. Kompetensi komunikatif memiliki banyak faktor sehingga peserta didik atau santri dapat berbahasa dan berkomunikasi dengan baik.Mereka diberikan pengajaran yang lebih serta diperkuat dengan latihanlatihan.Kompetensi komunikatif menurut Kridalaksana (dalam Ghazali, 2010: 48) adalah kemampuan bahasawan untuk mempergunakan bahasa yang secara sosial dapat diterima dan memadai. Paulson (dalam Ghazali, 2010: 49) menafsirkan bahwa kompetensi komunikatif adalah interaksi linguistik dalam bahasa sasaran yaitu kemampuan untuk berfungsi dalam setting yang betul-betul komunikatif.Paultson (dalam Ghazali,2010: 49) membedakan antara kompetensi linguistik dan kompetensi komunikatif untuk menekankan perbedaan yang sangat penting anatara pengetahuan tentang kaidah-kaidah bahasa dan struktur-struktur bahasa dan pengetahuan yang memungkinkan seseorang untuk berkomunikasi secara efektif dalam berbagai interaksi secara berhadaphadapan.

\section{Kompetensi Komunikatif dalam Proses Pembelajaran}

4.1 Kompetensi Komunikatif Bagi Santri Asrama

Proses pembelajaran bahasa yang berada di lingkungan asrama akan mengacu pada pengajaran bahasa kedua setelah bahasa pertama atau dikenal dengan bahasa ibu.Bahasa kedua adalah bahasa yang diperoleh di luar lingkungan keluarga, (Akhadiah, dkk 1997: 128).Bahasa kedua ini berada di luar lingkungan keluarga, melainkan bahasa kedua ini di pelajari di dalam lingkungan formal maupun nonformal. Proses pembelajaran yang diberikan bagi para santri yang tinggal di asrama memiliki perbedaan dengan santri yang tidak tinggal di asrama. Santri asrama akan diberikan teori-teori mengenai pembelajaran bahasa serta didukung dengan latihan-latihan yang memperkuat teori yang sudah diberikan di lingkungan formal atau sekolah. Pembelajaran bahasa kedua dipengaruhi oleh beberapa faktor. Berkaitan dengan pengajaran yang diberikan di asrama bagi santri asrama faktor yang mempengaruhi kompetensi komunikatif mereka adalah faktor situasional. Santri akan belajar pada situasi atau keadaan yang mengharuskan mereka untuk belajar berbahasa. Mereka sudah masuk dalam lingkungan yang memiliki program untuk belajar bahasa yang lebih produktif. Maka, para santri harus mengikuti program-program yang sudah ada di asrama tersebut. Dari faktor situasional juga dipengaruhi oleh pendekatan pengajaran. Para pengajar atau pendidik yang berada di lingkungan asrama memberikan pendekatan pengajaran yang lebih mendalam dalam pembelajaran bahasa bagi para santri. Para pengajar atau pendidik lebih menekankan pada kompetensi komunikatif bagi para santri, untuk memberikan penguatan terhadap apa yang sudah dijelaskan. Dari peran serta para pengajar ini bisa melahirkan para santri yang bisa berkomunikasi dengan bahasa yang produktif. Kreativitas dari seorang guru juga sangat menunjang proses pembelajaran khususnya pembelajaran bahasa dalam berkomunikasi, (Wahyudi, 2011: 108).

Kompetensi komunikatif tidak hanya mencakup penguasaan tata bahasa dan kosakata, tetapi juga Rules of Speaking misalnya: 
mengetahui saat dan cara yang tepat untuk membuka percakapan, topic yang tepat untuk tindak tutur tertentu, cara menyapa dan memveri, menginterpretasi: salam, pujian, permintaan maaf, undangan dan keluhan Wolfson (dalam Nurhadi ,2010: 85).

\subsection{Kompetensi Komunikatif bagi Santri \\ Nonasrama}

Santri nonasrama memiliki kemampuan komunikasi yang berbeda dengan santri asrama, karena pembelajaran yang diberikan kepada santri asrama lebih ditekankan pada pengembangan bahasa khususnya dalam pengembangan komunikasi. Dibandingkan dengan santri nonasrama, pembelajaran yang diberikan hanya berupa teori-teori yang diberikan dibangku sekolah atau lingkungan formal dengan tidak menggunakan latihanlatihan sebagai penguat dari teori yang sudah diberikan. Lingkungan formal adalah salah satu lingkungan belajar bahasa yang menfokuskan pada penguasaan kaidah atau aturan-aturan bahasa secara sadar dalam bahasa targer Dulay (dalam Nurhadi, 2010: 118).Para santri nonasrama tidak terikat oleh pembelajaran yang ada di lingkungan asrama, sehingga mereka tidak terikat dengan semua program-program yang berlaku di lingkungan asrama. Mereka menggunakan bahasa yang kurang produktif karena tidak ditunjang dengan latihan. Pembelajaran bahasa yang baik tidak hanya didapatkan di lingkungan formal akan tetapi dapat juga ditunjang di luar lingkungan formal. Pembelajaran bahasa di sekolah merupakan pembelajaran bahasa kedua. Pembelajaran bahasa kedua ini dipengaruhi oleh beberapa faktor, salah satu faktor yang mempengaruhinya adalah faktor situasional yaitu situasi pendekatan pengajaran,karakteristik guru.

Ellis (dalam Nurhadi, 2010: 119) bahwa urutan perkembangan (route of development) dalam pemerolehan bahasa adalah urutan tataran yang harus dilalui oleh pembelajar bahasa untuk menguasai bahasa target.Perkembangan bahasa ini dibagi menjadi dua yaitu order of development, dan sequence of development. Order of development adalah konsep perkembangan yang mengacu pada urutan pemerolehan aspek-aspek gramatikal yang bersifat spesifik dalam pembelajaran bahasa kedua. Sedangkan, sequence of development adalah konsep perkembangan yang mengacu pada semua bentuk perkembangan dalam pembelajaran bahasa kedua yang bersifat universal, yakni perkembangan pembelajaran bahasa kedua yang tidak dipengaruhi oleh latar belakang bahasa pertama pembelajar dan konteks pembelajaran.. Menurut Dulay (dalam Nurhadi ,2010: 130) lingkungan kebahasaan di sekolah termasuk lingkungan formal. Lingkungan ini diciptakan oleh guru dalam mendidik para siswanya.Sedangkan menurut Ellis (dalam Chaer, 2009: 243) menyebutkan dua tipe pembelajaran bahasa yaitu tipe naturalistik dan tipe formal di dalam kelas. Jika dibandingkan dengan pembelajaran bahasa oleh Ellis tersebut maka bahasa didapatkan dalam dua lingkungan, lingkungan yang berasal dari lingkungan kehidupan masyarakat tanpa adanya guru melainkan bisa terjadi karena unsur kesengajaan. Sedangkan yang formal akan berada di dalam kelas atau lingkungan sosial.

Tabel. 1.1

Aspek-aspek penilaian kompetensi komunikatif santri asrama dan nonasrama dalam kompetensi berpidato, (Nurgiyantoro, 2011: 420)

\begin{tabular}{|c|c|c|c|c|c|c|}
\hline \multirow[t]{2}{*}{ No } & \multirow{2}{*}{$\begin{array}{l}\text { Aspek yang } \\
\text { dinilai }\end{array}$} & \multicolumn{5}{|c|}{$\begin{array}{l}\text { Tingkat } \\
\text { Kinerja }\end{array}$} \\
\hline & & 1 & 2 & 3 & 4 & 5 \\
\hline 1. & $\begin{array}{l}\text { Kesesuaian isi } \\
\text { pembicaraan }\end{array}$ & & & & & \\
\hline 2. & $\begin{array}{l}\text { Kesesuaian isi } \\
\text { dengan tema } \\
\text { yang } \\
\text { disampaikan }\end{array}$ & & & & & \\
\hline 3. & $\begin{array}{l}\text { Ketepatan } \\
\text { dalam } \\
\text { melafalkan } \\
\text { bunyi-bunyi } \\
\text { vocal }\end{array}$ & & & & & \\
\hline 4. & $\begin{array}{l}\text { Ketepatan } \\
\text { dalam } \\
\text { menggunakan } \\
\text { intonasi dalam } \\
\text { berbicara }\end{array}$ & & & & & \\
\hline 5. & $\begin{array}{l}\text { Kesesuaian } \\
\text { dalam } \\
\text { penggunaan } \\
\text { mimik (gerak }\end{array}$ & & & & & \\
\hline
\end{tabular}




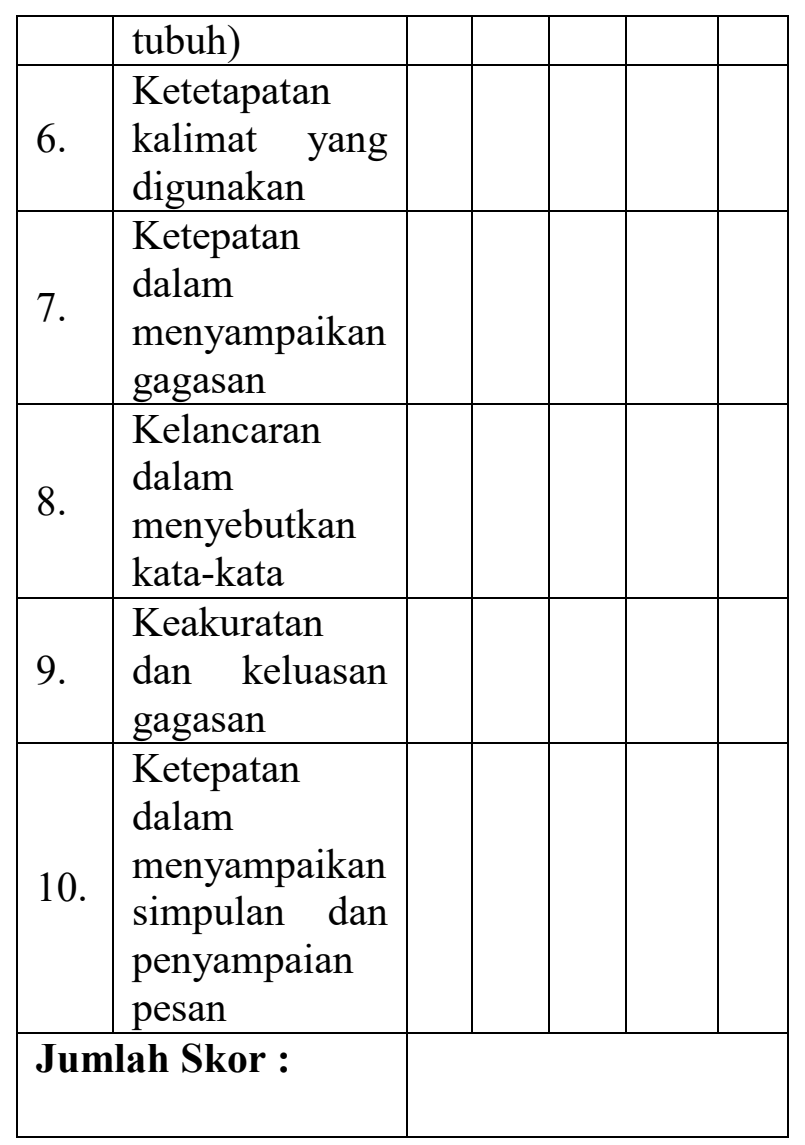

\section{METODE PENELITIAN}

Metode yang digunakan dalam penelitian ini berupa metode penelitian kausal komparatif (Causal Comparative Reseach),yang juga disebut dengan penelitian ex post facto adalah penyelidikan empiris yang sistematis di mana ilmuwan tidak mengendalikan variabel bebas secara langsung karena eksistensi dari variabel tersebut pada dasarya tidak dapat dimanipulasi. Kesimpulan tentang adanya hubungan di antara variabel tersebut dibuat berdasarkan perbedaan yang mengiringi variabel bebas dan variabel terikat, tanpa intervensi langsung (Kerlinger dalam Emzir, 1973: 379) Dalam penelitian ex post facto peneliti berusaha menentukan penyebab atau alasan, untuk keberadaan perbedaan dalam perilaku atau status kelompok individu. Pada penelitian ini ada dua katagori santri yang akan menjadi perbandingan. Santri yang berada di asrama dan santri yang tidak tinggal di asrama. Oleh karena itu, dalam penelitian akan dibandingkan kompetensi komunikatif yang dimiliki oleh santri asrama dan nonasrama.

\section{HASIL PENELITIAN \\ 1 Deskripsi Data}

Data yang didapatkan dari hasil penelitian berupa data hasil perhitungan kompetensi komunikatif yang diambil dari berpidato. Penilaian data berpatokan pada 10 kriteria dalam kompetensi berpidato. Dari jumlah masing-masing sampel adalah 15 orang. Sampel terdiri dari santri asrama yang digolongkan ke dalam kelas eksperimen, dan sampel yang terdiri dari santri nonasrama yang digolongkan ke dalam kelas kontrol yang ke dua kelas tersebut masing-masing memilki 15 sampel, sehingga sampel pada penelitian ini berjumlah 30. Dari hasil penelitian didapatkan nilai tertinggi dan nilai terendah dari masingmasing kelas.

Tabel 1.2 Tabel deskripsi data santri asrama dan santri nonasrama

\begin{tabular}{|c|c|c|c|c|c|}
\hline $\begin{array}{c}\text { Kelomp } \\
\text { ok }\end{array}$ & $\begin{array}{c}\text { Jumlah } \\
\text { siswa }\end{array}$ & $\begin{array}{c}\text { Nilai } \\
\text { tertingg } \\
\text { i }\end{array}$ & $\begin{array}{c}\text { Nilai } \\
\text { terendah }\end{array}$ & $\begin{array}{c}\text { Nilai } \\
\text { rata- } \\
\text { rata }\end{array}$ & $\begin{array}{c}\text { Standar } \\
\text { deviasi }\end{array}$ \\
\hline Asrama & 15 & 92 & 76 & 84.2 & 6.5 \\
\hline $\begin{array}{c}\text { Nonasra } \\
\text { ma }\end{array}$ & 15 & 76 & 45 & 58.7 & 9.85 \\
\hline Jumlah & 30 & & & & \\
\hline
\end{tabular}

Berdasarkan data hasil tes pada kompetensi komunikatif berpidato diperoleh kelas eksperimen dengan jumlah siswa 15 orang dengan nilai tertinggi 92, nilai terendah 76 dengan rata-rata (mean) 84.2 dan standar deviasi (SD) 6.5. Sedangkan untuk kelas kontrol jumlah siswa 15 orang dengan nilai tertinggi 76 dan nilai terendah 45 , diperoleh rata-rata (Mean) 58.7 dan standar deviasi (SD) 9.85. dari tabel di atas dibuat sebagai keperluan untuk pengkategorian dan perhitungan data. Untuk memperoleh besarnya rata-rata ideal (Mi) dan Standar Deviasi Ideal (SDi) digunakan rumus yang sudah ditentukan di bab III. Karena skor maksimal idealnya 100 dan skor minimalnya 0 (0) maka diperoleh:

$$
\begin{aligned}
& \mathrm{Mi}=\frac{1}{2}(100+0)=50 \text { dan } \\
& \mathrm{SDi}=\frac{1}{6}(100-0)=16,67
\end{aligned}
$$


Tabel 1.3 Tabel Konversi Skor Hasil Kompetensi Komunikatif dalam Berpidato

\begin{tabular}{|l|l|l|}
\hline Interval & $\begin{array}{l}\text { Konversi } \\
\text { Nilai }\end{array}$ & Kategori \\
\hline $\begin{array}{l}\text { Mi + 1 SDi } \\
\text { sampai Mi } \\
+3 \text { SDi }\end{array}$ & $100,67-$ & Tinggi \\
\hline $\begin{array}{l}\text { Mi - 1 SDi } \\
\text { sampai < } \\
\text { Mi + SDi }\end{array}$ & $66,67-$ & Sedang \\
\hline $\begin{array}{l}\text { Mi - 3 SDi } \\
\text { sampai }<\text { Mi } \\
-1 \text { SDi }\end{array}$ & $0-33,34$ & Rendah \\
\hline
\end{tabular}

Berdasarkan tabel di atas rata-rata yang diperoleh yaitu 84.2 yang dilihat dari interval rata-rata ideal ditambah 1 dengan Standar Deviasi Ideal sampai rata-rata ideal ditambah 3 Standar Deviasi Ideal dengan konversi nilai 66,67 - 100. Dari rata-rata yang diperoleh yaitu untuk santri asrama adalah 84.2 secara umum dapat digolongkan pada katagori tinggi, sedangkan untuk nonasrama yang rata-ratanya 58.7 dan dilihat dari intervalnya adalah rata-rata ideal dikurangi Standar Deviasi Ideal sampai rata-rata ideal kurang dari ditambah 1 Standar Deviasi Ideal dengan konversi nilai 33,33 66,67. Dari rata-rata yang diperoleh yaitu 58.7 maka termasuk dalam katagori sedang. Maka secara umum dapat digolongkan bahwa pencapain skor hasil tes pada aspek penilaian kompetensi komunikatif untuk berpidato pada santri yang berada di lingkungan asrama pada tahun 2014 termasuk dalam katagori tinggi untuk kelas eksperimen atau kelas santri asrama dan sedang untuk kelas santri nonasrama atau kelas kontrol.

Untuk lebih jelasnya dapat dilihat pada tabel berikut:

Tabel 1.4 Katagori nilai kedua kelompok

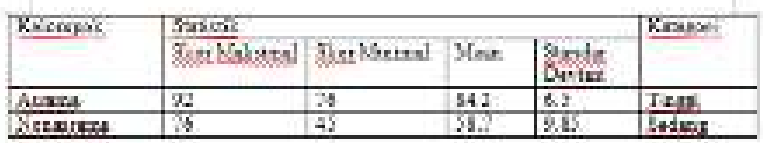

Dari tabel katagori nilai untuk kedua kelompok yaitu kelompok asrama yang mendapatkan skor maksimal adalah 92 dan skor minimal adalah 76, dengan rata-rata 82.2 untuk Standar Deviasinya adalah 6.5 sehingga dalam katagorinya tergolong ke dalam katagori tinggi.
Sedangkan untuk kelompok nonasrama skor maksimal adalah 76 dan skor minimal adalah 45 dengan rata-rata 58.7 untuk standar deviasi adalah 9.85. maka, untuk kelompok asrama digolongkan ke dalam katagori sedang.

Untuk mengetahui normalitas dari nilai santri asrama ini dapat dilihat pada rumus berikut :

1. Menentukan nilai tertinggi dan nilai terkecil

Nilai terbesar : 92

Nilai terkecil: 76

2. Menentukan Rentang (R)

$\mathrm{R}=92-76=16$

3. Menentukan Banyak Kelas (BK)

$$
\begin{aligned}
& \mathrm{BK}=1+3,3 \log \mathrm{n} \\
& \mathrm{BK}=1+3,3 \log 15 \\
& \mathrm{BK}=1+3,3 \times 1,18 \\
& \mathrm{BK}=1+3,89 \\
& \mathrm{BK}=4,89 \approx 5
\end{aligned}
$$

4. Menentukan Panjang Kelas

\begin{tabular}{|c|c|c|c|c|c|c|}
\hline So & $\begin{array}{l}\text { Kutas } \\
\text { letwaval }\end{array}$ & E & $\begin{array}{l}\text { Silat Trakati } \\
\text { dX]: }\end{array}$ & $\mathrm{xu}^{2}$ & Lxis & $t x^{2}$ \\
\hline 1 & $75-75$ & $T$ & 72 & sss:2,2s & dis: & 39105 \\
\hline 2 & Fi-xz & 2 & $x=, 2$ & $64 \$ 25$ & 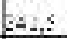 & 194465 \\
\hline 3 & $x i+3$ & 7 & 81.8 & $8.40,22$ & 83 & 7.40 .5 \\
\hline 1 & $8: 40$ & 4 & 85,5 & 7812,20 & 151 & $x+125$ \\
\hline \multirow[t]{2}{*}{, } & $9+1$ & 3 & \$1. & $x: \pm 0,2 ;$ & $\because 3,2$ & $2950 k, y 2$ \\
\hline & Janhl. & 15. & $4: 2 s$ & $s=2 \infty 1,2$ & $123 x$ & 1uters \\
\hline
\end{tabular}

$$
\mathrm{I}=\mathrm{R} / \mathrm{BK}=16 / 5=3,2=4
$$

5. Menentukan Nilai Rata-rata dan Simpangan

\section{Tabel 1.5 Nilai Rata-rata dan Simpangan}

Tebel 1.6 frekuensi yang diharapkan (fe) dari hasil pengamatan (fo) untuk kelas eksperimen

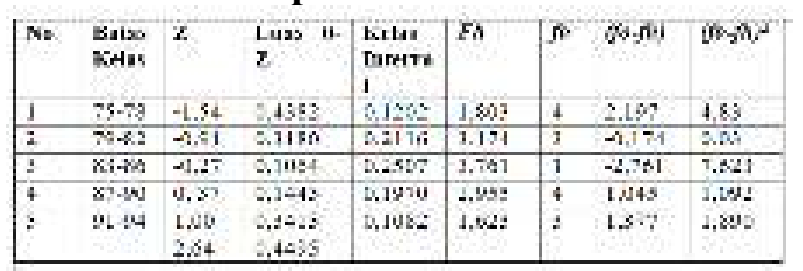

Tabel 1.7 Distribusi Frekuensi santri nonasrama

\begin{tabular}{|l|l|l|}
\hline No & Interval & $\begin{array}{l}\text { Frekuensi } \\
\text { mutlak }\end{array}$ \\
\hline 1 & $45-51$ & 5 \\
\hline 2 & $52-58$ & 3 \\
\hline 3 & $59-65$ & 2 \\
\hline 4 & $66-72$ & 4 \\
\hline 5 & $73-79$ & 1 \\
\hline & & 15 \\
\hline
\end{tabular}


Dari tabel di atas terlihat bahwa kelas ke-1 yaitu 45- 51 dengan jumlah frekuensi 5 orang siswa, kelas ke-2 yaitu 52 - 58 dengan jumlah frekuensi 3 orang siswa, kelas ke- 3 yaitu 59-65 dengan jumlah frekuensi 2 orang siswa, kelas ke-4 yaitu 66 - 72 dengan jumlah frekuensi 4 orang siswa, kelas ke-5 yaitu $73-$ 79 dengan jumlah frekuensi 1 orang siswa. Dari semua jumlah frekuensi tersebut dapat dijumlahkan menjadi 15, maka frekuensi tersebut sesuai dengan jumlah sampel dari santri nonasrama. Sehingga didapatkan frekuensi terbesar terletak pada kelas ke- 1yaitu 45 - 51 dengan frekuensi 5 orang.

Untuk mengetahui normalitas santri nonasrama maka dapat digunakan rumus sebagai berikut :

1. Menentukan nilai terbesar dan nilai terkecil

Nilai terbesar : :76

Nilai terkecil :45

2. Menentukan rentang $(\mathrm{R})$

$\mathrm{R}=76-45=31$

6. Menentukan Banyak Kelas (BK)

$\mathrm{BK}=1+3,3 \log \mathrm{n}$

$\mathrm{BK}=1+3,3 \log 15$

$\mathrm{BK}=1+3,3 \times 1,18$

$\mathrm{BK}=1+3,89$

$\mathrm{BK}=4,89 \approx 5$

3. Menentukan panjang kelas (i)

$\mathrm{i}=\mathrm{R} / \mathrm{BK}=31 / 5=6,2=7$

4. Menentukan nilai Rata-rata dan Simpangan Baku

Tabel 1.8 Nila Rata-rata dan Simpangan Baku

\begin{tabular}{|c|c|c|c|c|c|c|}
\hline $\mathrm{Nu}$ & $\begin{array}{l}\text { Keir } \\
\text { Interin: }\end{array}$ & F & $\begin{array}{l}\text { Nilii Teı̨̧ } \\
\mathrm{X}_{1}\end{array}$ & $\mathrm{Xi} z$ & CX: & $\mathrm{IXi} \mathrm{i}^{2}$ \\
\hline I & $45-51$ & $s$ & 4a & 2.304 & 240 & 11520 \\
\hline 2 & $52 \cdot 58$ & I & 55 & 3025 & 265 & surs \\
\hline 3 & 50.65 & 2 & 62 & 3844 & 124 & 3688 \\
\hline 4 & 65.72 & 4 & 69 & 4761 & 270 & 19044 \\
\hline 5 & $73-79$ & 1 & 76 & 5976 & 36 & 5776 \\
\hline \multicolumn{2}{|c|}{ 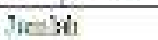 } & 15 & 310 & & 881 & $3 \leqslant 103$ \\
\hline
\end{tabular}

Tebel 1.9 frekuensi yang diharapkan $\left(f_{h}\right)$ dari hasil pengamatan $\left(\mathrm{f}_{\mathrm{o}}\right)$ untuk kelas kontrol

\begin{tabular}{|c|c|c|c|c|c|c|c|c|}
\hline No & $\begin{array}{l}\text { Tists } \\
\text { Keiss }\end{array}$ & 2 & $\begin{array}{l}16 \pi \\
2.2\end{array}$ & $\begin{array}{l}\text { zeles } \\
\text { illexi }\end{array}$ & $I_{4}$ & is & $50-4$ & $2 \mathrm{C}-\mathrm{St}^{\circ}$ ? \\
\hline 1 & $45-51$ & $-1,45$ & 0,0596 & 0.2077 & 3.115 & 3 & 1.59 & 3.5721 \\
\hline 2 & 32.38 & -273 & 02673 & 0.2593 & 3,3695 & $\hat{3}$ & $-3,8395$ & 6.51 \\
\hline 3 & 59.55 & 3.02 & 00000 & 0,3629 & 29435 & 2 & -1.944 & 3.73 \\
\hline 2 & 66.72 & 0,68 & 024.49 & 0,643 & 24545 & L & -1.54 & 2.36 \\
\hline \multirow[t]{2}{*}{5} & $73 \cdot i y$ & $-14 \%$ & 0,4192 & 0,6624 & $\cos \mathrm{t}$ & 1 & $0, .49$ & 0.0224 \\
\hline & & $2,1 !$ & 0.4826 & & & & & \\
\hline
\end{tabular}

Setelah dilakukan uji normalitas maka selanjutnya adalah uji homogenitas data dari kedua kelompok yaitu kelompok santri asrama dan kelompok santri nonasrama. Untuk mengetahui homogennya kedua kelompok ini maka dapat dipergunakan rumus sebagai berikut

Tabel 1.10 Kerja Untuk Menghitung $\chi^{2}{ }_{o b s}$

\begin{tabular}{|c|c|c|c|c|c|}
\hline sampl & $f_{i}$ & $\$ s$ & $s_{j}^{2}$ & $x_{0} \mathrm{~s}_{1}^{2}$ & $f \log s^{2}$ \\
\hline $\begin{array}{l}\text { Kelsi } \\
\text { Ch noximual }\end{array}$ & 14 & 23960.83 & 1711,49 & 3.233 & 45,262 \\
\hline $\begin{array}{l}\text { Esals } \\
\mathrm{B} \times \mathrm{m}=\mathrm{ll}\end{array}$ & 14 & 13300,33 & 960,24 & 2.9778 & 41.690 \\
\hline Jumlal & 28 & $\begin{array}{l}372641 \\
5\end{array}$ & & & 85,952 \\
\hline
\end{tabular}

1. Daerah Kritik:

$$
\chi_{\alpha ; k-1}^{2}=\chi_{0,05 ; 2-1}^{2}=\chi_{0,05 ; 1}^{2}=3,841
$$

2. Kriteria Uji:

Jika $\chi_{\text {hitung }}^{2}<\chi_{\text {tabel }}^{2}$, maka $\mathrm{H}_{0}$ diterima (Sampel homogen).

$$
\chi_{\text {hitung }}^{2} \geq \chi_{\text {tabel }}^{2} \text {, maka } \mathrm{H}_{0} \text { ditolak }
$$
(Sampel tidak homogen).

3. Keputusan Uji

$\mathrm{H}_{0}$ diterima karena $1,06266<3,841$

4. Kesimpulan:

Sampel berasal dari populasi yang homogen

Berdasarkan pengujian yang sudah dilakukan maka dapat disimpulkan bahwa kelompok santri asrama dan kelompok santri nonasrama tergolong ke dalam kelompok yang homogen. Artinya adalah kedua kelompok ini mula-mula memiliki kemampuan yang sama dalam kompetensi berpidato, akan tetapi setelah mereka memiliki tempat tinggal yang berebeda yaitu kelompok yang tinggal di asrama dengan kelompok yang tidak tinggal di asrama memiliki kemampuan yang berebeda. Sehingga kedua kelompok ini dikatakan homogen.

Setelah melakukan uji normalitas dan uji homogenitas, maka yang terahir adalah uji hipotesis. Untuk mengetahui apakah hipotesis yang diajukan diterima atau ditolak, maka dapat dilihat pada pengujian hipotesis berikut ini.

Adapun rumus yang digunakan adalah uji-t polled varians, rumusnya sebagai berikut : $t=\frac{\bar{X}_{1}-\bar{X}_{2}}{\sqrt{\frac{\left(n_{1}-1\right) s_{1}^{2}+\left(n_{2}-1\right) s_{2}^{2}}{n_{1}+n_{2}-2}\left(\frac{1}{n_{1}}+\frac{1}{n_{2}}\right)}}$ 
Ho : Tidak terdapat perbedaan kompetensi komunikatif antara santri asrama dan nonasrama di Pondok Pesantren Ulil Albaab.

Ha : Terdapat perbedaan kompetensi komunikatif antara santri asrama dan nonasrama di Pondok Pesantren Ulil Albaab.

$\mathrm{H}_{\mathrm{a}}: \mu_{1} \neq \mu_{2}$ (ada perbedaan)

$\mathrm{H}_{0}: \mu_{1}=\mu_{2}$ (tidak ada perbedaan)

1. $\alpha=0,05$

2. Statistik uji yang digunakan:

$t=\frac{\bar{X}_{1}-\bar{X}_{2}}{\sqrt{\frac{\left(n_{1}-1\right) s_{1}^{2}+\left(n_{2}-1\right) s_{2}^{2}}{n_{1}+n_{2}-2}\left(\frac{1}{n_{1}}+\frac{1}{n_{2}}\right)}}$ Komputasi:

Rata-rata $(\overline{\mathrm{X}})$, Standar Deviasi (s), Varians $\left(s^{2}\right)$, dan Korelasi (r):

$$
\begin{array}{cc}
\overline{\mathrm{X}}_{1}=84,2 & \overline{\mathrm{X}}_{2}=58,7 \\
\mathrm{~s}_{1}=6,3 & \mathrm{~s}_{2}=9,85 \\
\mathrm{~s}_{1}{ }^{2}=39,69 & \mathrm{~s}_{2}{ }^{2}=97,0225
\end{array}
$$

$$
\begin{gathered}
t=\frac{\bar{X}_{1}-\bar{X}_{2}}{\sqrt{\frac{\left(n_{1}-1\right) s_{1}^{2}+\left(n_{2}-1\right) s_{2}^{2}}{n_{1}+n_{2}-2}\left(\frac{1}{n_{1}}+\frac{1}{n_{2}}\right)}} \\
=\frac{84,2-58,7}{\sqrt{\frac{14.39,69+14.97,0225}{15+15-2} \times\left(\frac{1}{15}+\frac{1}{15}\right)}}
\end{gathered}
$$

3. Daerah

Kritik:

$\mathrm{t}_{0,025 ; \mathrm{dk}}=\mathrm{t}_{0,025 ; \mathrm{n}_{1}+\mathrm{n}_{2}-2}=\mathrm{t}_{0,025 ; 15+15-2=} \mathrm{t}_{0,025 ; 30-2}=\mathrm{t}_{0,025}$

4. Keputusan uji:

Karena $-t_{\text {tabel }}<t_{\text {hitung }}>+t_{\text {tabel }}$ atau $2,048<2,969>2,048$, maka $\mathrm{H}_{0}$ ditolak dan

$\mathrm{H}_{\mathrm{a}}$ diterima.

5. Kesimpulan:

Terdapat perbedaan kompetensi komunikatif antara santri asrama dan nonasrama di Pondok Pesantren Ulil Albaab.

Berdasarkan hasil uji dan perhitungan di atas, maka dapat dismpulkan bahwa hipotesis Ha dapat diterima karena ada perbedaan kompetensi komunikatif antara santri asrama dan nonasrama di pondok pesantren Ulil Albaab dan menolak Ho yang menyatakan tidak ada perbedaan kompetensi komunikatif santri asrama dan nonasrama di Pondok Pesantren Ulil Albaab.

\section{Uji Persyaratan Analisis}

a. Uji Normalitas Data

Pembuktian normalitas data dimaksud untuk menguji apakah skor variabel-variabel yang diteliti telah mendekati distribusi normal atau tidak. Variable yang dibuktikan normalitas datany adalah data hasil tes aspek penilaian pada kompetensi komunikatif dalam berpidato. Untuk menganalisis data tersebut digunakan rumus Chi- Kuadrat $(\lambda)$ hasil yang diperoleh (hitung $\lambda$ ) dicocokkan dengan $(\lambda)$ yang ada pada tabel dengan taraf signifikan $5 \%$ dan taraf keabsahan untuk uji ini adalah (k-1), di mana $\mathrm{k}$ adalah banyaknya kelas interval. Adapun kriteria yang digunakan adalah sebagai berikut:

Jika $(\lambda)$ hitung yang diperoleh lebih besar dari harga $(\lambda)$ yang ada pada tabel, maka data yang diperoleh tidak berdistribusi normal. Dan sebaliknya, jika harga $(\lambda)$ hitung kurang dari $(\lambda)$ tabel maka data yang diperoleh

\begin{tabular}{|c|c|c|c|}
\hline Kelompos: & $\mathrm{X}^{2}$ than? & $X_{\text {tabst }}^{3}$ & Kuttera \\
\hline Asrama & 6.254 & 9,488 & Texdistribusi aomal \\
\hline Nonastana & 3,5925 & 9,488 & Terdistribus aomal \\
\hline
\end{tabular}
berdistribusi normal.

Tabel 1.11 Ringkasan Uji Normalitas Data Kompetensi Komunikatif dalam Berpidato

Dari Tabel dapat dilihat bahwa nilai $\mathrm{X}_{28}^{2}$ \#巴 6,254 dan $\mathrm{X}^{2}$ tabel adalah 9,488, dikatakan mencapai kriteria terdistribusi normal. Kelompok santri asrama mencapai kriteria terdistribusi normal karena $\mathrm{X}_{\text {hitung }}^{2}<\mathrm{X}^{2}$ tabel atau 6, $254<9,488$. Sedangkan untuk kelompok santri nonasrama $X^{2}{ }_{\text {hitungadalah } 3,5925}$ dan $\mathrm{X}_{\text {tabel }}^{2}$ adalah 9,488, maka kelompok santri nonasrama juga dikatakan terdistribusi normal, karena $X^{2}{ }_{\text {hitung }}<X_{\text {tabelatau }}^{2} 3,5925<9,488$. Maka, masing-masing kelompok lebih kecil dari nilai $\mathrm{X}_{\text {tabel }}^{2}$ pada taraf nyata $5 \%$, sehingga dapat disimpulkan bahwa kedua kelompok berasal dari sampel yang terdistribusi normal.

b. Uji Homogenitas Data

Uji homogenitas bertujuan untuk mengetahui apakah kelompok eksperimen dan kelompok kontrol berasal dari sampel yang 
sama (homogen). Data yang digunakan untuk menentukan homogen atau tidaknya kedua kelompok diambil dari hasil tes akhir untuk masing-masing kelompok. Berikut ini akan disajikan secara ringkas pada Tabel di bawah, dan perhitungan secara rinci dapat dilihat pada lampiran ke 7.

Tabel. 1.12 Ringkasan Uji Homogenitas Kompetensi Komunikatif dalam Berpidato

\begin{tabular}{|l|l|l|l|l|}
\hline No & Kelas & $\mathrm{N}$ & $\mathrm{F}_{\text {hitung }}$ & $\mathrm{F}_{\text {tabel }}$ \\
\hline 1 & Asrama & 15 & 1,06266 & 3,841 \\
\hline 2 & $\begin{array}{l}\text { Nonasra } \\
\text { ma }\end{array}$ & 15 & & \\
\hline
\end{tabular}

Pada tabel di atas dapat dilihat bahwa kelas asrama berjumlah 15 dan kelas nonasrama berjumlah 15 maka didapatkan $\mathrm{F}_{\text {hitung }}=1,06266<\mathrm{F}_{\text {tabel }}=3,841$. Sesuai dengan kriteria yang ada yaitu apabila $F_{\text {hitung }}<F_{\text {tabel }}$ maka kedua kelompok tersebut yaitu kelompok santri asrama dan kelompok santri nonasrama berasal dari sampel homogen, artinya kedua kelompok mempunyai kemampuan awal yang sama.

\section{c. Pengujian Hipotesis}

Setelah terpenuhi prasyarat analisis tersebut, maka dapat dilakukan uji hipotesis untuk mengetahui apakah hipotesis yang telah diajukan diterima atau ditolak. Mengingat jumlah santri kedua sampel $\left(n_{1} \neq n_{2}\right)$ dan jika varians homogen $\left(s_{1}^{2}=s_{2}^{2}\right)$, maka data hasil penelitian dianalisis dengan mengunakan uji-t polled varian. Hasil perhitungan secara ringkas ditunjukkan pada tabel berikut:

Tabel 1.13 Pengujian Hipotesis

\begin{tabular}{|c|c|c|c|c|c|c|}
\hline Sanpe: & $\begin{array}{l}\text { Junlui sutn } \\
\text { (n) }\end{array}$ & $\bar{X}$ & s & $s^{3}$ & $i_{\text {mar }}$ & tos \\
\hline Asrema & 15 & 82,2 & 6,3 & 39,89 & \multirow[t]{2}{*}{$3,34 y$} & \multirow{2}{*}{2.948} \\
\hline Senasxm! & 13 & $58, ?$ & 9,55 & 97,0125 & & \\
\hline
\end{tabular}

Berdasarkan tabel di atas, sampel dari kelas asrama berjumlah 15 orang atau $\mathrm{N}=15$, dengan Mean $(\bar{X})=82,2$ dan Standar Deviasi (s) $=6,3$ dan Varians $\left(s^{2}\right)=39,69$. Sedangkan untuk kelas dari sampel kontrol berjumlah 15 atau $\mathrm{N}=15$, rata-rata atau Mean $(\bar{X})=58,7$ Standar Deviasi $(\mathrm{s})=9,85$ dan varians $\left(s^{2}\right)=$ 97,0225. Makadidapatkan $t_{\text {hitung }}=2,969$ dant $_{\text {table }}=$
2,048 dengan derajat kebebasan $\mathrm{dk}=\mathrm{n}_{1}+\mathrm{n}_{2}-$ $2=15+15-2=28$ pada taraf siginifikansi $5 \%$. Perbandingan menunjukkan bahwa $-t_{\text {tabel }}<$ $t_{\text {hitung }}>+t_{\text {tabel }}$ atau2,048<2,969>2,048, maka $\mathrm{H}_{0}$ ditolak dan $\mathrm{H}_{\mathrm{a}}$ diterima.Penyebab dari $\mathrm{H}_{\mathrm{o}}$ ditolak adalah harga $\mathrm{t}_{\text {tabel }}<\mathrm{t}_{\text {hitung. }}$. Sedangkan $\mathrm{H}_{\mathrm{a}}$ diterima karena $\mathrm{t}_{\text {hitung }}>\mathrm{t}_{\text {tabel }}$. Hal ini berarti "Ada perbedaan kompetensi komunikatif antara santri asrama dan nonasrama di Pondok Pesantren Ulil Albaab..

Dengan demikian, santri yang berada di lingkungan asrama memiliki kompetensi komunikatif yang lebih baik khusunya dalam bidang berpidato, dibandingkan dengan santri yang tidak tinggal di asrama. Perbedaan tersebut terjadinya karena beberapa faktor seperti adanya penambahan pembelajaran yang diperkuat dengan latihan-latihan. Sehingga dalam pembelajaran dapat disimpulkan bahwa penyampaian teori saja tidak cukup dalam proses pembelajaran melainkan harusditambah dengan latihan-latihan dari pemahaman teori tersebut.

\section{KESIMPULAN}

Berdasarkan dari hasil penelitian dan pembahasan dari penelitian ini, maka dapat ditarik kesimpulan sebagai berikut:

Dari hasil uji hipotesis didapat nilai $t_{\text {hitung }}$ $>t_{\text {tabel }}$ ini berarti hipotesis nol $\left(\mathrm{H}_{0}\right)$ yang menyatakan bahwa "tidak terdapat perbedaan kompetensi komunikatif santri asrama dan nonasrama di Pondok Pesantren Ulil Albaab" ditolak. Danhipotesis alternatif (Ha) yang berbunyi "terdapat perbedaan kompetensi komunikatif santri asrma dan nonasrama di Pondok Pesantren Ulil Albaab" diterima.

\section{DAFTAR PUSTAKA}

Akhadiah, Sabarti,dkk.1997.Teori Belajar Bahasa.Jakarta : Penerbit Universitas Terbuka.

Aslinda,dkk.2007.Pengantar Sosiolinguistik.Bandung:PT Refika Aditama

Chaer, Abdul. 2009. Psikolinguistik Kajian Teoretik. Jakarta:PT. Rineka Cipta.

Devito, A. Joseph. 2011. Komunikasi Antarmanusia. Selatan:Karisma Publishing Group. 
Emzir.2012. Metodelogi Penelitian Pendidikan Kuantitatif dan Kualitatif. Jakarta:PT Raja Grafindo Persada.

Ghazali, Syukur H.A.2010.Pembelajaran Keterampilan Berbahasa DenganPendekatanKomunikatifInteraktif.Bandung:PT Refika Aditama.

Nurgiyantoro, Burhan. 2011. Penilaian Pembelajaran Bahasa Berbasis Kompetensi. Yogyakarta : BPFE.

Nurgiyantoro, Burhan.2011.Penilaian Otentik Dalam Pembelajaran Bahasa.Yogyakarta: Gadjah Mada University Press.

Nurhadi . 2010. Dimensi-Dimensi dalam Belajar Bahasa Kedua. Bandung : Sinar Baru Algensindo.

Purwanto. 2012. Metodelogi Penelitian Kuantitatif Untuk Psikologi Dan Pendidikan. Yogyakarta: Pustaka Pelajar.

Rakhmat, Jalaluddin. 2012. Metode Penelitian Komunikasi Dilengkapi Dengan Contoh Analisis Statistik. Bandung: PT Remaja Rosdakarya.

Sugiyono. 2010. Metode Penelitian Kuantitatif Kualitatif Dan R\&D. Bandung: Alfabeta.

Syamsudin, dkk. 2006. Metode Penelitian Pendidikan Bahasa.Bandung : PT Remaja Rosdakarya.

Tarigan, Henry Guntur.2008.Berbicara Sebagai suatu Keterampilan Berbahasa.Bandung: Percetakan Angkasa.

Tarigan,HenryGuntur.2009.PengajaranKompe tensiBahasa.Bandung:PercetakanAngkas a.

Budiyono. 2009. Statistika untuk penelitian. Surakarta: UNS Press 